\title{
The effect of web-related features on intention to use online banking of ATM users
}

\author{
Khalid AL-Zu' bi ${ }^{\mathbf{a}^{*}}$ \\ ${ }^{\mathrm{a} A l-B a l q a}$ Applied University, Jordan

\section{H R O N I C L E} \\ Article history: \\ Received: June 18, 2021 \\ Received in revised format: June \\ 29, 2021 \\ Accepted: August 4, 2021 \\ Available online: August 4, 2021 \\ Keywords: \\ Online banking \\ Intention \\ Web-related features \\ Banks \\ Customers \\ Jordan
}

\section{A B S T R A C T}

\begin{abstract}
This study aimed to determine the intention of ATM users in Jordan to use internet banking services by investigating the effect of web-related features on their intention to use internet banking. The study sample was randomly selected. The results indicated that the level of internet banking usage among employees who use the ATM service is still underutilized. Also, computer self-efficacy significantly mitigated the effect of perceived risk, website quality, and perceived benefit on customers' intent to use online banking but did not significantly mitigate the impact of perceived use and compatibility on customers' intent to use online banking. The results can be useful for commercial banks that have implemented online banking in all their applications or are planning to do so. The study also provides benefits to academic researchers interested in the topic researched, commercial banks, commercial bank customers.
\end{abstract}

(C) 2021 by the authors; licensee Growing Science, Canada.

\section{Introduction}

The Internet has played a major role in changing the business operations and processes practiced in the organizations and thereby it changed policies and strategies that had to be built by the organizational management to keep business activities aligned with the customers' requirements. Nowadays, top management in the organizations inevitably find themselves obliged to plan for short-term objectives because of the changeable market requirements and fast-worldwide competitive products and services. According to Zabadi (2016), the diverse and additional demands in the organizations made by today turbulent competitiveness caused major challenges to the current information systems' capabilities, lead to persuade the organizations to develop more sophisticated and comprehensive information systems matching the competitive market (Ali, 2019; Raza et al., 2015). Banking sector is one of these organizations that have been affected by internet remarkable business changes and without pursuing business development and renewable market needs, banks will not keep their competition in the marketplace. Online banking (internet banking) is one of the internet-based systems playing remarkable effects on the banks' market by retaining the current customers and getting new ones; by online banking, banks can introduce services that obviously exceed the traditional banking services through providing fast, convenient, and wide range services (Ong et al., 2017). Therefore, they must ensure the customers that the online services supplied by them are greater than that introduced by a face-to-face encounter to feel that online services are more differentiated than the traditional channels (Alwan \& Al-Zu'bi, 2016). Customers always search for convenient, short-time, available, and responsive services. Such these services and more others can be provided by online banking. By using internet, simply, a customer can access his/her account, transfer money from acount to another, recharge e-cards, pay bills, and pay online to buy goods or services (Vivi \& Novita, 2017). In this case, the customer reduces much more time, efforts, and costs than that may be consumed when visiting the physical branch (Katiyar \& Badola, 2018; Krisnato, 2017).

* Corresponding author.

E-mail address: Khalid.Zoubai@bau.edu.jo (K. AL-Zu’bi)

(C) 2021 by the authors; licensee Growing Science, Canada. doi: $10.5267 /$ j.ijdns.2021.8.004 
Internet banking is considered as an important part of e-banking and plays a major role in its growth (Raza et al., 2015). According to Sikdar et al. (2015), for banks, the major benefits gained from the internet banking include the recruitment of fewer numbers of employees, lower error rate and paperwork, and better fund management, but for customers, the major benefits include higher level of convenience and any-time availability of services. Compared with its expansive usage in the developed countries, Online banking in Jordan is still somehow underused and at its unsatisfactory level of adoption by customers. Online banking has not yet taken off in Jordan as much as imagined (Rawashdeh, 2015; Alwan \& Al-Zu'bi, 2016). To enhance the consumer adoption of online banking, it is very persistent for Jordanian financial institutions to make key improvements that can help them understand their consumers' concerns and determine factors influencing their adoption of this technology (Abu-Assi et al., 2014). This means that more efforts at the two levels, management and research, should be devoted to investigate the challenges facing online banking acceptance and expansion at the banks' customers. Online banking in Jordan still needs more support to be aligned with that in the developed countries. There are obstacles against the acceptance and usage of online banking (Al-Rfou, 2013; Unyathanakorn \& Rompho, 2014). This study is directed to search for this problem. It is focused on the ATM users in Jordan to identify the current state of online banking, their intention to use online banking, obstacles of not to use this technology, and provide some suggested solutions that may help banks to open their eyes to plan robust strategies that may support this innovative technology development and reinforce its usage by their customers.

\section{Research Problem, Importance, \& Objectives}

\subsection{Research problem}

Depending on the prior research concerning with e-banking in Jordan (Abu-Assi et al., 2014; Alwan \& Al-Zu'bi, 2016; Rawashdeh, 2015), and compared with ATM as commonly used e- banking system, online banking acceptance by the customers in addition to the development level speed of this information technology are still unsatisfied and need more support by the research and banks' management. This indicates that there is an urgent need for more development in this field and more flexible techniques to persuade more customers to use this innovative technology. Web-related features provide very important e-applications and properties that help customers to easily achieve many e-services (Ali, 2019; Vivi \& Novita, 2017). For that, the study aims to propose a new model that may integrate web-related features (factors) with intention to use online banking in Jordanian banking environment. Therefore, the study problem can be manifested in these questions:

- What is the current state of online banking usage by ATM users of commercial banks in Jordan?

- What are the critical factors controlling intention to use online banking by ATM users of commercial banks in Jordan?

- What is the effect of computer-self efficacy as moderator on the relationship between web-related features and customers' intention to use online banking?

\subsection{Research importance}

As online banking offers the customers many advantages including low costs, time/location convenience, speed, and ease of performing transactions, it provides the banks with lower costs, convenience, availability, and responsiveness. For that, nowadays, it is the most e-banking technology used in the developed countries, but it is still little used in the Middle East countries. This study takes its importance from its concentration on investigating barriers inhibiting customers in Jordan from using this innovative technology widely and being deprived of its many benefits.

\subsection{Research aim and objectives}

The aim of the study is to propose a new model that may describe the relationship between web-related features and intention to use online banking by the customers who are accustomed to using ATM service as an e-banking system. Based on the literature review that discussed many issues of online banking and the problem statement, the study's aim leads to three objectives:

- To evaluate the current level of online banking usage by the customers of Jordanian commercial banks.

- To measure the effect of web-related features on the intention to use online banking by banks' customers.

- To provide some suggestions for the top management of Jordanian banks to enhance the level of online banking usage among their customers.

\section{Theoretical Background}

This part of the study provides theoretical background information about online banking, technology acceptance model (TAM), and all variables of web-related features that were discussed in literature review concerning the study's variables.

\subsection{Online banking in Jordan}

Although Jordanian banks witness pivotal banking services and try to be the pioneer in the Middle East in adopting what is new in information technology, they still do not apply online banking in a satisfactory level compared with the developed countries. Jordanian banks adopted internet banking in 2000. During the period of 2001 to 2003, they did not realize the concept of internet banking, and it was just an informative type that allows the customer to see all the bank's products and 
services without any interaction (Abu-Assi et al., 2014). Then, they upgraded their websites to apply the communicative type of internet banking application that allows their customers to interact with the bank's system by sending accounts' queries, updating accounts' files, and applying loans' processes (Rawashdeh, 2015). According to Siam (2006), Jordanian commercial banks moved from the communicative to the transitional stage in which the customer can perform his banking transactions independently through internet-based applications, where he can use his personal computer as a client connected to the internet to access his accounts, transfer funds from his own account to another, and pay online anywhere and anytime. Simply, the customer can just access the bank's website, select "internet banking" or "E-banking" option, enter the main account number registered on his e-card, and enter its security number (Association of Banks in Jordan: ABJ, 2018), once the process of the account's access has been implemented successfully, the customer achieves many banking services online, such as account's inquiry, transactions' inquiry, funds' transfer between accounts, request of credit card, request of check, etc. At the end of 2007, 16 banks from the 24 Jordanian commercial banks provided functional services of internet banking (Abu-Shanab \& Pearson, 2009). These internet banking services were limited and varied among the banks. By this highly developed step, Jordanian banks achieved competitive advantage by reducing costs and increasing responsiveness. However, since 2012, most of Jordanian commercial banks have improved their websites to be transactional in several financial processes (ABJ, 2018). According to Association of Banks in Jordan (2018), the commercial banks in Jordan, national and foreign, developed their websites to include a wide range of online banking services. Today, there are fifteen main online banking services provided to the customers by their banks (Table 1). Additionally, there are many secondary online services provided by the Jordanian commercial banks to their customers, such as applying for a loan, order ATM card, donation, change of password, the payment of social security benefits, prepaid cards (ex-links), standing order request, fixed deposit breakage, etc. Up to 2014, Jordanian commercial banks promised their customers by providing them with online pay - bills' service as a new online service persistently required by their customers, and by the beginning of 2015 , the service was implemented and ready to use by the banks 'customers (ABJ, 2018).

Table 1

Main Online Banking Services provided by Jordanian Banks

\begin{tabular}{|c|c|c|c|}
\hline Type of service & $\begin{array}{l}\text { Number of banks } \\
\text { that provide the } \\
\text { service }\end{array}$ & Type of service & $\begin{array}{l}\text { Number of } \\
\text { banks that } \\
\text { provide the }\end{array}$ \\
\hline Inquire about account balances & 19 & Regular payment orders and conversion & 11 \\
\hline Inquire about details of accounts & 19 & Pay bills & 9 \\
\hline Transfer to a third party in dinars or foreign currencies & 15 & Credit card request & 9 \\
\hline Inquire about transactions made on the account & 18 & Check request & 17 \\
\hline Transfer between accounts in dinars or in foreign currencies & 18 & Request statement of account for a specific & 17 \\
\hline Request to change the title & 11 & \multirow{3}{*}{ Querying bulletin interest rates } & \multirow{3}{*}{11} \\
\hline Pay mobile phone bills & 8 & & \\
\hline Querying bulletin of foreign currencies' prices & 15 & & \\
\hline
\end{tabular}

\subsection{Technology Acceptance Model (TAM)\& its Modifications.}

Many business models were developed to explain the acceptance of a new information technology, but technology acceptance model (TAM) introduced by Davis(1989) was the mostly abroad one used by many researchers, and it effectively proved its success. TAM argues that the intention to use a new information system/technology by an individual is affected by two factors: perceived usefulness (PU) and perceived ease of use (PEOU). PEOU is affected by PU and both affect "intention to use" which itself affects the behavioral usage of the information system. Later, Davis et al. (1992) modified the TAM model to include other factors that may affect the two main factors (PEOU and PU). In the new modified TAM, enjoyment and perceived usefulness were found to have entirely indirect impact on the usage behavior through their effects on the intention to use a new information technology. Also, the two factors (enjoyment and perceived usefulness) mediate fully the effect of perceived ease of use and output quality on intention to use a new technology. Moreover, task importance moderated the effect of perceived ease of use and output quality on perceived usefulness but not enjoyment. Because all online banking transactions are processed on the internet, the customers need to practice their financial operations safely and securely. This reason motivated researchers interested in this field to add perceived risk emerging from security and privacy to the two TAM original factors (PU \& PEOU). Jahangir and Begum (2007) postulated a model that conceptualized the direct relationship between the independent variables (perceived usefulness, ease of use, security and privacy) and adaptation to e-banking. It was found that there are direct paths from these variables toward the customer's adaptation. Banks' customers are demanding online banking services not less than traditional services with more developed functions such as effective interactivity and availability. This inevitable requirement encouraged researchers to add website quality to TAM to be more adaptive to online services. Through an empirical study about business to customer e-commerce website quality and its impact on the customer's intention to online banking usage, Cao et al. (2005) investigated factors constituting website quality. The results of their study indicated that information quality, system quality, and service quality of a website plays a major role in affecting a customer's perception of online banking. Generally, individuals seem to be more inclined to use online services if they find it compatible with their lifestyle and their values. In the literature of e-banking, compatibility was used with other factors relating to innovativeness models, such as complexity, trialability, and observability. Owing to its importance, in this study, Compatibility was used to be tested with the main TAM components. Eriksson et al. (2008) extended the applicability of the innovation 
model to online banking adoption in Estonia. Their study's results showed that the relative advantage and compatibility have the strongest influence on online banking acceptance.

\section{Research Model \& Hypotheses}

\subsection{Research model}

The research model (Fig. 1) was used to test the relationship between factors that are described as "web-related features" and "intention to use online banking". Based on the literature, the factors: "perceived risk", "perceived usefulness", "perceived ease of use", "website quality", and "compatibility" were used as independent variables (IV), whereas" intention to use online banking (IUOB)" was used as dependent variable (DV). Description below explains these variables.

\subsubsection{Web-related features}

Web-related features express characteristics of the bank's website that help users to perform their activities and tasks. In the online banking system, the customer depends on these features when he needs to implement financial transactions effectively. In his study that aimed at identifying the relationship between consumer's attitudes, system's characteristics and internet banking adoption in Malaysia, Ndubisi and Sinti results (2006) showed that attitudinal disposition and web features can predict internet banking adoption. Their study explained four main factors having strong influence on internet banking adoption, which are: compatibility, complexity, trialability, and importance to banking needs, but perceived risk was found to have a weak influence. Poon (2008) found that accessibility, convenience, website features are considered as sources of satisfaction. Moreover, he added that some factors including speed, availability, service fees, and bank's operation management were described as critical factors in spite of their lower level than the major factors. Through the literature above we can hypothesize that:

\section{$\mathbf{H}_{1}$ : WEB-Related features have a significant positive effect on intention to use online banking at the significance level.}

\subsubsection{Perceived risk (PR)}

Perceived risk is mainly involved in the customer's concerns about system's safety and security needed in transferring funds and managing financial assets (Apostolos et al., 2012). Perceived risk has an impact on online banking acceptance but negatively, where customers stay reluctant to use online banking systems because of online banking security and information privacy (Agarwal \& Vohra, 2012). According to Oweis and Alghaswyneh (2019), cash operations are still managed through the relationship's managers, instead banks have an opportunity to get competitive advantage by offering more secure online cash management functionality comprising overnight borrowings, lines of credit approvals, and real-time liquidity. Risks emerging from web privacy and security will exert a negative impact on online banking acceptance, because once consumers perceive the potential risks coming from unsafe financial transactions, they would not reuse online service (Rawashdeh, 2015).

Through the literature above, we can hypothesize that:

H1-a: Perceived risk has a significant negative effect on intention to use online banking.

\subsubsection{Website quality (WSQ)}

Moving from legacy systems and integrating them with new internet-based applications is a very sensitive step to confirm quality insurance. Redesigning the banks' websites to be a more intuitive user friendly interface (UFI) should provide real benefits and save much time to users leading to increasing the customers' stickiness to their banks (Pan et al., 2014). Well designed websites' features should be able to provide more secure services and thus reduce perceived risk associated with financial transactions. It can be confirmed that well designed websites' features have a negative impact on perceived risk and a positive impact on perceived ease of use, this will lead to increase the customer's trust, which will motivate his intention to use online banking (Kesharwani \& Bisht, 2012), website quality is related to the customer's perceived ease of use and perceived usefulness and further to customer intention to use the bank's website (Cao et al., 2005).

Through the literature above, we can hypothesize that:

$\mathbf{H}_{1-\mathbf{b}}$ : Website quality has a significant positive effect on intention to use online banking.

\subsubsection{Perceived ease of use (PEOU)}

Difficulty in using computer and e-banking applications' related to the perceived self- service is considered as one of the main barriers facing use of online banking (Karjaluoto et al., 2003; Khan et al., 2016). Casaló et al. (2008) suggested several alternatives to improve the level of customer loyalty, and to develop positive word-of-mouth in e-banking business. One of these alternatives is ease of use, since the most effective website may not be the most sophisticated one, but the most effective and easy to use, banks must manage their websites' perceived usability. Online banking is considered efficient if the customer finds it easy to use (Calisir \& Gumussoy, 2008; Mojares, 2014).

Through the literature above, we can hypothesize that:

H1-c: Perceived ease of use has a significant positive effect on intention to use online banking. 


\subsubsection{Perceived usefulness (PU)}

Perceived usefulness has more influence than perceived ease of use in explaining new technology acceptance (Pikkarainen et al., 2004; Unyathanakorn \& Rompho, 2014).According to Khan et al. (2016), the both factors mentioned in TAM (perceived ease of use and perceived usefulness) have important effect on a new technology acceptance, but perceived usefulness has more effective importance. Perceived ease of use has less impact on the technology acceptance than perceived usefulness, because as users learn more about the use of a new technology, they become more informative about its benefits and then more satisfied in its acceptance (Deraz \& Iddris, 2019; Sundarraj \& Wu, 2005). Therefore:

H1-d: Perceived usefulness has a significant positive effect on intention to use online banking.

\subsubsection{Compatibility (CP)}

When a new information system or a new information technology is perceived to be compatible with an individual's experience and his working style, it will be more likely to provide a feeling of familiarity that will result in its faster usage. Compatibility has an indirect impact on intention to use online banking through perceived ease of use, perceived usefulness, and security and privacy (Adapa, 2011; Kartiwi \& Rfied, 2018). Compatibility with a new online banking application makes customers perceive online banking easier to use and more useful, then they will be more prepared to use this new technology (Apostolos et al., 2012). Kolodinsky et al. (2004) empirically examined how characteristics that describe adoption of an innovation can be correlated to the adoption of e-banking technologies. Their study applied the theories of technology acceptance and the diffusion of innovation to the adoption of e-banking services, such as auto-bill payment. In their study, compatibility was found to have a significant and positive influence on e-banking adoption. Through the literature above, we have:

$\mathbf{H}_{1-\mathrm{e}}:$ Compatibility has a significant positive effect on intention to use online banking.

\subsubsection{Computer-self Efficacy (CSE)}

Computer self-efficacy refers to an individual confidence to use computer-based applications. Without knowledge of computer and internet practices, the user may see online banking complex and not useful, then he/she may not use it. Therefore,

$\mathbf{H}_{2}$ : Computer-self Efficacy has a significant positive effect on intention to use online banking.

Computer self-efficacy enables the user to deal effectively with the web related features and easily identify the positions and standards of the services' quality. Karjaluoto et al. (2003) stated that computer-self efficacy influences intention to use a new information technology through perceived ease of use, perceived usefulness and credibility. This means that the user with higher computer self-efficacy is more likely to get more awareness about perceived use, usefulness, and security that will make him more likely to use online banking. Without Computer self-efficacy, the user may not be able to use a new information technology and feel that his online financial information is more exposed to permeation (Kesharwani \& Bisht, 2012). Through the literature above, we can hypothesize that:

H3: Computer self-Efficacy significantly moderates the relationship between web-related features and intention to use online banking.

H3-a: Computer self-efficacy significantly moderates the relationship between perceived risk and intention to use online banking.

$\mathbf{H}_{3-\mathbf{b}}$ : Computer self-efficacy significantly moderates the relationship between website quality and intention to use online banking.

H-c: Computer self-efficacy significantly moderates the relationship between perceived ease of use and intention to use online banking.

$\mathbf{H}_{3-\mathrm{d}}$ : Computer self-efficacy significantly moderates the relationship between perceived usefulness and intention to use online banking.

H-e: Computer self-efficacy significantly moderates the relationship between compatibility and intention to use online banking.

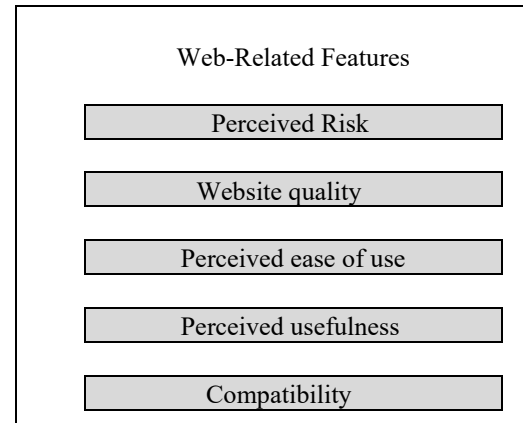

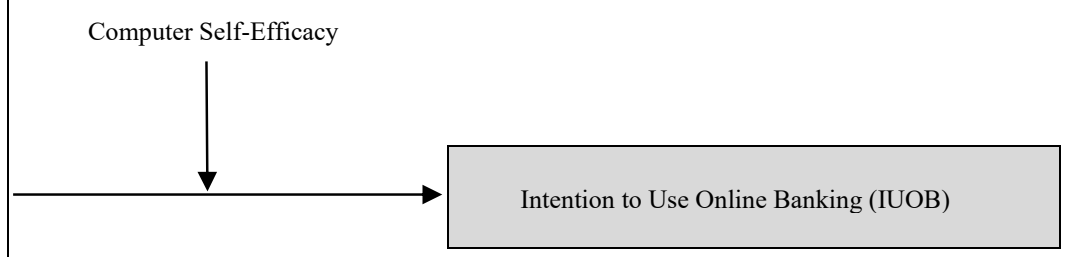

Fig. 1. Research model 


\section{Research Method}

\subsection{Measurement of scales}

To ensure the content validity of the scales, the items selected must represent the concept about which generalizations are to be made (Bohmstedt, 1970). The study questionnaire was developed using items adopted from the previous validated inventory and adapted to validate measurement of intention to use online banking by ATM users in Jordan. 15 Items for measuring perceived risk, perceived usefulness, and perceived ease of use were adapted from (Ali, 2019; Al-Sukkar, 2005; Jaruwachirathanakul \& Fink, 2005). Five items for measuring website quality were adapted from (He \& Mykytyn, 2008; Liang \& PeiChin, 2015). Six items for measuring compatibility were adapted from (Eriksson et al., 2008; Wang et al., 2003). Eight items were adapted from (Karjaluoto et al., 2003; Calisir \& Gumussoy, 2008) to measure computer- self efficacy. Seven items were adapted from (Alwan \& Al-Zu'bi, 2016; Karjaluoto et al., 2003) to measure intention to use online baking. The questionnaire consists of two sections: The first section is composed of questions relating to the demographics of respondents, whereas the second one is composed of questions measuring the effect of some factors on intention to use online banking using FiveLikert scale (strongly disagree, disagree, neutral, agree, and strongly agree).

\subsection{Study population \& sampling}

To achieve the study's aim and its objectives, the banks' customers accustomed to ATM, as an e-banking system commonly used by Jordanian customers and through which they mostly look forward to a more effective e-banking system, were taken as the targeted population of the study. Balqa university employees' community working as administrators and lecturers in their variant departments, having banking accounts, using ATM as e-banking system, were taken to represent the study population. The study population community was composed of (1175) employees. The study sample was selected randomly and regardless of partiality. For confidence of $(95 \%)$, and error level of $(5 \%)$, the sample size is (290). To get the sample size completely (290), the questionnaire was delivered to (360) employees eligible to the study requirements. From the total delivered questionnaires (360), 18 questionnaires were not responded and 27 were not filled properly. Therefore, the number of the retrieved and properly filled questionnaires was (315) representing (87.5\%) of all distributed questionnaires and completely represented the sample size (290). After three weeks of the questionnaires' distribution, the data collected were organized and analyzed, and the model's hypotheses were tested using SPSS tools.

\section{Results \& Discussion}

The collected data from the study sample were organized and analyzed using a set of analytical techniques in SPSS. Then, the results were discussed depending on the researcher's viewpoints supported by some previous studies.

\subsection{Results}

\subsubsection{Demographic characteristics of the respondents}

The study selected its sample impartially to get more accurate results. The demographics, here, included gender, age, income level, experience of using the internet, and use of online banking. For each demographic field, the majority will be taken for discussion. For age, $28 \%$ of the respondents were of age 35 to less than 40 . This infers that most of the respondents intending to use online banking are youth who are active and enthusiastic to use e-media and try to shorten their daily operational time as much as possible by focusing on the homeless work. $68 \%$ of the respondents intending to use online banking were from male gender. This may explain that females are more cautious in using the internet to not be victim to security issues. $35 \%$ of the respondents intending to use online banking are paid highly (more than $2000 \mathrm{JDS}$ ), which means that people with high income are more inclined to use online banking. For internet-based experience, $45 \%$ of the respondents intending to use online banking were of more than 15 internet-based experience years. This interprets that people with internet experience may look for online banking as easy to use and have the ability to discover its benefits and be more knowledgeable of its probable risks. $12 \%$ of the respondents use online banking to achieve their financial transactions. This means that a small percent of the respondents depend on online transactions more than traditional banking.

\subsubsection{Testing reliability}

Cronbach's Alpha was used for measuring the internal consistency among the items of each variable, which should be not less than 0.60 (Nunnally, 1978) and composite reliability among the main variables which should be not less than 0.70 (Haire et al., 2000).

Table 2

Reliability Statistics for the Variables

\begin{tabular}{ccc}
\hline Variable & Cronbach's Alpha For Each Variable & Cronbach's Alpha For All Variables \\
\hline PR & 0.866 & 0.836 \\
WSQ & 0.861 & 0.87 \\
PU & 0.858 & 0.833 \\
CP & 0.869 \\
CSE & 0.854 & \\
\hline IUOB &
\end{tabular}


Table 2 shows that the internal reliability for all variables' items were greater than 0.60 , and the results of measuring the composite reliability for all variables $(0.87)$, which is greater than 0.70 . This means that the result of the study's reliability is accepted.

\subsubsection{Testing multi-collinearity}

A strong correlation among the model's variables may reflect negatively on the measurements of its hypotheses, reason that may result in necessity for adapting or deleting some variables. Tolerance and Variance Inflation Factor (VIF) were used for testing multi-collinearity. When the value of Tolerance test is found not less than 0.1 and that of VIF not greater than 10, it can be said that there is not multi-collinearity problem (Kleinbaum et al., 1988). Also, correlation coefficients between Webrelated features were significant and did not exceed the critical correlation level $(0.80)$. Therefore, it can be said that there is not multi-collinearity problem in the study. Table 3 shows the results of testing multi-collinearity.

Table 3

Tolerance and Variance Inflation Factor (VIF) of the Variables

\begin{tabular}{|c|c|c|c|c|c|c|c|c|}
\hline Variable & Tolerance & VIF & PR & WSO & PEOU & $\mathrm{PU}$ & $\mathrm{CP}$ & CSE \\
\hline PR & 0.701 & 1.427 & 1 & $0.54^{* *}$ & $0.73^{* *}$ & $0.74^{* * *}$ & $0.61^{* *}$ & $0.74^{* *}$ \\
\hline WSQ & 0.388 & 1.708 & & 1 & $0.62^{* *}$ & $0.49^{\text {*** }}$ & $0.78^{* *}$ & $0.69^{* *}$ \\
\hline PEOU & 0.585 & 1.943 & & & 1 & $0.74^{* * *}$ & $.55^{* * *}$ & $0.58^{* *}$ \\
\hline PU & 0.515 & 2.649 & & & & 1 & $0.57^{* *}$ & $0.49^{* *}$ \\
\hline $\mathrm{CP}$ & 0.378 & 2.576 & & & & & 1 & $0.71^{* *}$ \\
\hline CSE & 0.64 & 1.64 & & & & & & 1 \\
\hline
\end{tabular}

\subsubsection{Testing hypotheses}

Multiple linear regression analysis techniques were conducted by three steps through three models to test the hypothesis at significance level of (0.05). In the first model, the main independent variables were tested against IUOB as the dependent variable at significance level of (0.05). As shown in table (4), for all predictors, $\mathrm{R}^{2}$ explains $(40.8 \%)$ of the variance related to IUOB, which means that the effect size for the entire model is accepted. Also, the entire model has a significant effect on IUOB $(F=28.268, P<0.05)$, which means that we can accept the main hypothesis (H1) that hypothesized a significant and positive effect of "web-related features" on "intention to use online banking".

Table 4

Model summary of web-related features (IV) and IUOB (DV)

\begin{tabular}{cccc}
\hline Model Summary & \multicolumn{1}{c}{ ANOVA } & S \\
\hline $\mathrm{R}$ & $\mathrm{R}^{2}$ & $\mathrm{~F}$ & \\
\hline 0.639 & 0.408 & 28.268 & $0.000^{* *}$ \\
\hline
\end{tabular}

Note: (a) Predictors: (constant), PR, WSQ, PEU, PU, CP; (b) Dependent variable: IUOB

Particularly, the standardized coefficients (Beta) value for the independent variables: WSQ, PU, and CP are positive and significant $(0.461,0.326,0.131)$, and the critical value $(p$-value $)$ obtained with $\alpha=(0.05)$ is $(0.000,0.001,0.049)$ respectively. For PR, the standardized coefficient (Beta) is negative and significant (- 0.183) and the critical value $(p$-value) obtained with $\alpha=(0.05)$ is $(0.031)$, whereas the standardized coefficient (Beta) value for PEU is not significant $(0.021)$ and the critical value ( $p$-value) obtained with $\alpha=(0.05)$ is $(0.792)$. Table (5) shows the coefficients (Beta) for the predictors (PR, WSQ, PEOU, $\mathrm{PU}$, and $\mathrm{CP}$ ) and the dependent variable (IUOB). Table (5) shows coefficients of web-related features and intention to use online banking.

Table 5

Coefficients of web-related features (IV) and IUOB (DV)

\begin{tabular}{|c|c|c|c|}
\hline Model 1 & Standardized coefficients (Beta) & $\mathrm{t}$ & Sig. \\
\hline Constant & & 2.973 & $0.003^{* *}$ \\
\hline PR & -0.183 & -2.183 & $0.031^{*}$ \\
\hline WSQ & 0.461 & 4.791 & $0.000^{* *}$ \\
\hline PEU & 0.021 & 0.265 & 0.792 \\
\hline PU & 0.326 & 3.341 & $0.001^{* *}$ \\
\hline $\mathrm{CP}$ & 0.131 & 1.834 & $0.049^{*}$ \\
\hline
\end{tabular}

Notes: $* \mathrm{p}<0.05 ; * * \mathrm{p}<0.01 ;$ Dependent Variable: Intention to use online banking (IUOB)

According to the table above (Table 5), we can accept the hypotheses: (H1-a, H1-b, H1-d, and H1-e), that confirm a significant effect of perceived risk, website quality, perceived usefulness, and compatibility, respectively, on "intention to use online banking" and reject the hypothesis (H1-c), which confirms a significant impact of "perceived ease of use" on "intention to use online banking". Secondly, by step two, in (Model 2), computer self-efficacy was tested whether it significantly affects IUOB (dependent variable) at significance level of (0.05). It was found that $\mathrm{R}^{2}$ explains $(51.4 \%)$ of the variance related to IUOB, and computer self-efficacy significantly affected IUOB with beta value of $(0.807),(\mathrm{p}<0.05)$. According to this result, we can accept hypothesis (H2), which confirms a significant impact of "Computer self-efficacy" on "intention to use online 
banking". Table 6 shows the coefficients (Beta) for the predictor "computer self-efficacy" and the dependent variable (IUOB). Table 6 shows coefficients of computer self-efficacy and intention to use online banking.

Table 6

Coefficients of computer self-efficacy (IV) and IUOB (DV)

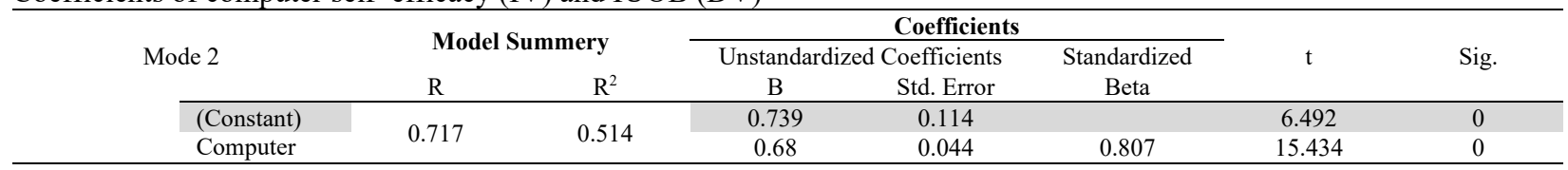

a. Dependent Variable: IUOB

b. Predictors: (Constant), computer self-efficacy

By the third step, in (Model 3), the moderator (computer self-efficacy) was multiplied by the predictors generating new interaction terms (interaction variables), thus, there were five interaction terms. Then, the interaction variables were entered into the regression model to be tested against the dependent variable (IUOB). The interaction results indicated that $\mathrm{R}^{2}$ explains $(51.1 \%)$ of the variance related to IUOB, (increased with percent of $(10.3 \%)$ from the base model). For the entire model, webrelated factors' predictor was significantly moderated by computer self-efficacy $(F=48.036, P<0.05)$ with significant change of F-value by (15.173). The change in F- value here indicates that the most recent contribution (computer self-efficacy) represents a significant improvement in the predictive power of the regression equation. Table 7 shows the entire model of web-related features and computer self-efficacy interaction process.

Table 7

Model summary of the interaction between computer self-efficacy and web-related features.

Model 3 Model Summary

\begin{tabular}{ccccccc}
\multicolumn{3}{c}{ Model Summary } & \multicolumn{3}{c}{ ANOVA } \\
\hline $\mathrm{R}$ & $\mathrm{R}^{2}$ & $\Delta \mathrm{R}^{2}$ & $\mathrm{~F}$ & Sig. & $\Delta \mathrm{F}$ & Significant $\Delta \mathrm{F}$ \\
\hline 0.715 & 0.511 & 0.103 & 48.036 & 0 & 15.173 & 0 \\
\hline
\end{tabular}

Note: (a) Model 3: (constant), PR, WSQ, PEU, PU, CP, CSE, CSE $\times$ PR, CSE $\times$ WSQ, CSE $\times$ PEU, CSE $\times$ PU, CSE $\times$ CP; (b) Dependent variable: IUOB.

In the third model, perceived risk, perceived usefulness, and computer self-efficacy significantly affected (IUOB) at $(p \leq$ 0.05 ) with the standardized coefficient $($ Beta $=0.205,0.268$, and 0.315$)$ respectively, whereas website quality, perceived ease of use, and compatibility did not significantly affect (IUOB) at ( $p>0.05)$. In the interaction process, PR, WSQ, and PU were significantly moderated by computer self-efficacy with beta value of $(0.247),(0.315)$, and $(0.347) ;(p<0.05)$ respectively. PEU and CP were not significantly moderated by Computer self-efficacy where beta value is $(0.070),(0.045)(p>0.05)$ respectively. According to these results, we can conclude that for the third part of the hypothesis testing, the decision is to accept the hypotheses H3, H3-a, H3-b, H3-d, and reject the hypotheses H3-c and H3-e. Table 8 shows the coefficients of the interaction effect for all variables.

Table 8

Coefficients of the interaction between computer self-efficacy and web-related features

\begin{tabular}{|c|c|c|c|}
\hline Mode 2 & Standardized coefficients (Beta) & $\mathrm{t}$ & Significance \\
\hline constant & & 2.462 & $0.015^{*}$ \\
\hline PR & -0.205 & -2.064 & $0.041^{*}$ \\
\hline WSQ & 0.042 & 0.392 & 0.695 \\
\hline PEU & 0.018 & 0.277 & 0.82 \\
\hline PU & 0.268 & 2.623 & $0.010^{* *}$ \\
\hline $\mathrm{CP}$ & 0.028 & 0.36 & 0.72 \\
\hline CSE & 0.315 & 4.634 & $0.000^{* *}$ \\
\hline $\mathrm{CSE} \times \mathrm{PR}$ & -0.247 & -2.795 & $0.006^{* *}$ \\
\hline $\mathrm{CSE} \times \mathrm{WSQ}$ & 0.315 & 4.634 & $0.000^{* *}$ \\
\hline $\mathrm{CSE} \times \mathrm{PEU}$ & 0.07 & 0.839 & 0.403 \\
\hline $\mathrm{CSE} \times \mathrm{PU}$ & 0.347 & 3.526 & $0.001^{* *}$ \\
\hline $\mathrm{CSE} \times \mathrm{CP}$ & 0.045 & 0.604 & 0.547 \\
\hline
\end{tabular}

Notes: (a) $* \mathrm{p}<0.05 ; * * \mathrm{p}<0.01$; (b) Dependent Variable: Intention to use online banking (IUOB)

\subsection{Discussion}

The study results should be discussed in three layers: First, how the web-related features do affect intention to use online banking by the users of ATM service without a moderating factor (computer self-efficacy). Second, how computer selfefficacy affects intention to use online banking. Third, how web-related features affect intention to use online banking when being moderated by computer self-efficacy as a moderating factor related to the user's confidence to use computer and internet-based applications. In the first layer, the results in which factors were found positively affect customer's intention to use online banking (WSQ: Beta $=0.461$, PU: Beta $=0.326$, CP: Beta $=0.131$ ). This result is consistent with prior research (Eriksson et al., 2008; Jahangir and Begum, 2007). In general, a customer's ambition to use online banking needs to find useful events by that system matching, at least, or surpassing those provided by the conventional banking system. Jordanian customers who are using online banking gain some benefits, tangible or intangible, generated by that system. Such benefits include 
convenience, availability, responsiveness, integrity, etc. Moreover, the customer needs an online banking system to be compatible with his/her lifestyle to use it easily and flexibly. Undoubtedly, website quality, in terms of all its dimensions, plays a major role in retaining the current customers and getting new ones, because when the customers find some quality attributes absent, they may not try to reuse it; for instance, they may not reuse the bank website to get online banking services if reliability, assurance, responsiveness or more of these attributes are unavailable. When perceived risk was found negatively affects customers' intention to use online banking (PR: Beta $=-0.183$ ), this comes consistent to the prior research (Apostoloset al., 2012; Feathermanet al., 2010), which confirmed that the fear of risks emerging from applying online services mostly lead customers to be more cautious in using online services. This may be attributed to the customers' fear of unauthorized access to their financial accounts or hacking for their online transactions. However, this fear can be overcome by increasing the awareness of online services' safety and security. It is known that the customer needs to practice his financial operations as much as he does in face-to-face manner. Banks' management should continually try to develop their online banking applications in such a way that allows customers to accomplish their transactions safely and securely. After that, banks' management should give acknowledgments to their customers that their transactions will take place in a high level of security and privacy, and their funds are transferred through highly controlled e-constraints. Perceived ease of use is the only factor found not having a significant effect on customers' intention to use online banking in this study (PEU: Beta $=0.021$ ). This factor is correlated to the computer and internet-based skills of the users of this information technology. In Jordan, there is a large section of the community having knowledge in computer fields and the internet. Thereby, when an individual has eligible skills in this field, he may find the use of online banking easy to understand and practice. Hence, he/she may become looking forward to more complex features or practices, such as online banking system responsiveness, security, interactivity, integrity, etc. In the second layer, computer self-efficacy was found significantly affecting customer's intention to use online banking $($ Beta $=0.807, p$-value $<0.05)$. This result is consistent with (Lassar et al., 2005; Marakarkandy et al., 2017), which confirmed that computer self-efficacy enables the customers to be more motivated to use multiple internet-based applications to explore and navigate in online services. These services include various online banking services. Moreover, today, smart phones supported the banks' customers to practice online banking services easily and flexibly, especially, there is a large percent of people in Jordan depending on the internet by using smart phones to implement their requirements. Therefore, the customer in Jordan may just need to download an online banking application on his smartphone (e.g.: mobile phone) to implement his financial operations online, such as pay-bill, fund transfer, etc. The relationship between computer self-efficacy and intention to use online banking is very correlative. The prevalence of online services in Jordan boosted and increased the level of computer self-efficacy at the customer to the extent that he became more inclined to use online banking.

In the third layer, based on the result of model (2), in which computer self-efficacy significantly affected the customers' intention to use online banking asserting that computer- self efficacy is a very effective factor that helps customers to implement their transactions fast with little effort, computer self-efficacy was entered as a moderator to increase positively the effect of each web-related factor on a customer to accept online banking. It can be noticed that when computer self-efficacy was entered as a moderator to the entire model, it significantly and positively modified its effect on intention to use online banking $(F=48.036, P<0.05)$. This indicates that when a user has good skills and experience that increase his confidence to use internet and computer-based programs, he will be more inclined to accept and use online banking. By looking comparatively to the modified and unmodified values of the predictors' effect on intention to use online banking in model (3), it can be noticed that computer self-efficacy decreased the effect of perceived ease of use on intention to use online banking (Beta $=0.070, p$-value $=0.403>0.05)$, compared to the unmodified value $($ Beta $=0.018, p$ - value $=0.820>0.05)$. The impact of computer self-efficacy on customers' intention to use online banking is still not significant in the interaction process, because even the user had good confidence in his abilities to use his bank's website and practice his financial processes through an online banking application easily, and he may not reuse it if he feels that he may be vulnerable to some risks emerging from his online service transactions. It was found that computer self-efficacy increased positively the significant effect of perceived usefulness on intention to use online banking (PU: Beta $=0.347, p<0.05$ ). This may explain that when a customer has sufficient confidence in using computer and internet-based applications, he will be more capable to get more benefits from online services, such as dealing with complicated transactions or implementing rapidly many financial operations. With knowledge that these online benefits and many others are attained efficiently (reduced costs, time, and efforts). Computer self-efficacy increased negatively the effect of perceived risk (PR: Beta $=-0.247, p<0.05)$. This may be attributed to that when a customer becomes provided with more computer and internet-based capabilities, he may feel less courageous and more frightened to be vulnerable to the internet permeations or hacking, especially if he does not get enough acknowledgements from the bank's management about how to manage his financial transactions carefully and consciously. Computer selfefficacy increased negatively the significant effect of website quality on intention to use online banking (WSQ: Beta $=0.315$, $\mathrm{p}<0.05)$. This indicates that confidence in using computer and internet-based applications is highly related to the website quality service in such a way that may stressfully motivate customers to use online banking services. Computer self-efficacy may help the customer to evaluate the online service quality levels and motivate him attractively to use the service. Ultimately, for compatibility factor, computer- self efficacy decreased the insignificant effect of compatibility on intention to use online banking (Beta $=0.045, \mathrm{p}>0.05)$ compared to the unmodified value $(B e t a=0.028, \mathrm{p}>0.05)$. It can be noticed that computer self-efficacy does not affect online banking systems to be more compatible and familiar to the lifestyle and values of people using that system. The degree of the system-customer compatibility depends on the understanding of the bank's management to their customers' attitudes, values, and beliefs and then reflecting them on the online services' features and attributes. 


\section{Conclusion, Recommendations \& Future Research}

\subsection{Conclusion}

According to the literature of online banking in the developing countries, the rate of its use among customers is still low and thus needs more support from the banks' management and relative research. The study was focused to investigate the current situation of online banking adoption, besides determining the obstacles that may inhibit its acceptance and expansion at the banks' customers in Jordan by revealing the effect of web-related features on the intention of commercial banks' customers in Jordan to use this information technology. Because the study's aim is correlated to the intention to use online banking by the people who are accustomed to using the ATM system as a commonly used e-banking system in Jordan, Balqa university employees were taken as the study population. The study found that $(12 \%)$ of the customers accustomed to use ATM services use online banking. The study measured the effect of the factors: perceived risk, web-site quality, perceived ease of use, perceived usefulness, and compatibility against "intention to use online banking" by ATM users in Jordan. It was found that the factors "website quality, perceived usefulness, and compatibility" significantly and positively affect intention to use online banking, whereas perceived risk significantly and negatively affects the intention to use online banking, and ease of use has not significant impact. Moreover, when computer self-efficacy was used as a moderator on the relationship between webrelated features (IV) and intention to use online banking (DV), it was found that computer self-efficacy significantly moderated the relationship between perceived risk, website quality, and perceived usefulness (IV) and intention to use online banking (DV), but it does not significantly moderate the relationship between perceived ease of use and compatibility (IV) and intention to use online banking (DV).

\subsection{Recommendations}

By looking carefully at the customers' keenness of risks created by online banking, banks should try to give guarantees to their customers that their financial transactions should be dealt as safe as face-to face practices. At the same time, aligned with those acknowledgements, the banks should permanently pursue up-to-date security applications to protect their customers' accounts against any faults or hacking. As a community that is mostly familiar to internet usage in various fields, people in Jordan can accept a new idea easily and fast, especially if the new idea is provided by an organization having a standing position and devoting much effort to provide them with great advantages, such as online service availability, interactivity, security, and responsiveness. Thereby, Jordanian banks can use effective e - media (e.g.: short message system (SMS) on mobile phones, or social media such as FaceBook, Twitter, etc.) to make their customers constantly knowledgeable of new ideas such as online pay - taxes or e-invoicing. There are many transactions that the customers need to achieve periodically and are obligatory, such as paying bills in some fields, and thus need efficient facilities to do them. Jordanian banks must develop their information systems of online banking to include these essential requirements. Today online banking offers more developed payments' options for self-service. Jordanian banks have to introduce an e-invoicing tool that provides a wide range of payments' options with keeping user friendly and configurable interface that allows the customer to optimize the data field matching his just required transactions such as payment or transfer. This eligible behavior will make the payment easier to do, save much time, and reduce errors. By this way, the customers may try to accomplish their necessities and mostly look further to more developed online banking processes. As a progressive step, to reinforce the usage of e- cards commonly by Jordanian customers and to expand their benefits (e.g.: credit card, debit card) instead of any other boring ways, the banks in Jordan supported by Jordanian central bank (JCB) and association of Jordanian banks (AJB) should spread the consciousness among all the traditional markets as well as people about the efficiency of the online banking services. Additionally, they should strive to open multiple channels with these markets for the purpose of expanding the online banking services to include most or all services' fields to the extent that Jordanian customers can easily attain the required service conveniently by using just online banking related e-card.

\subsection{Limitations \& Future Research}

The study used web-related features as information system characteristics, such as perceived risk and perceived usefulness to be tested against intention to use online banking. This may make the study more specific and get more exact results, but there are some other factors not related to the information system and play an important role in getting customers to use online banking, such as banks' resources and banks' competition. Such factors can be added to the future research with regard to the time that may consume. The study was focused on the banks' customers represented in ATM users in Jordan because they are interested in the acceptance and use of this information technology, and it overlooked the other stakeholders responsible for upgrading and developing online banking applications. For more integrative viewpoints, the future research should consider the banks managers' opinions and online banking developers' suggestions about the customers' requirements and the suitable methods that must be considered for improvement or development of the online banking system as well as expansion of its acceptance at the Jordanian banks' customers. 


\section{References}

Abu-Assi, H., H. Al-Dmour, H., \& Al-Zu’bi, Z. M. F. (2014). Determinants of internet banking adoption in Jordan. International Journal of Business and Management, 9(12). doi:10.5539/ijbm.v9n12p169

Abu-Shanab, E., \& Pearson, M. (2009). Internet banking in Jordan: An Arabic instrument validation process". The International Arab Journal of Information Technology, 6(3), 235-246.

Adapa, S. (2011). Continued and frequent use of internet banking by Australian consumers: Identification of the factor components". The Journal of Internet Banking and Commerce, 16(2), 1-22.

Agarwal, S. \& Vohra, S. (2012). Factors affecting usage of online banking services, available at :http://papers.ssrn.com/sol3/papers.cfm?abstract_id $=2087215$.

Ali, L. (2019). Cyber crimes-A constant threat for the business sectors and its growth (A study of the online banking sectors in GCC). Journal Of Developing Areas, 53(1), 267-279.

Al-Rfou, A. N. (2013). The usage of online banking evidence from Jordan". Asian Economic and Financial Review, 3(5), $614-623$.

Al-Sukkar, A. S. (2005). The application of information systems in the Jordanian banking sector: a study of the acceptance of the internet.

Alwan, H. A., \& Al-Zu'bi, A. I. (n.d.). Determinants of internet banking adoption among customers of commercial Banks: An empirical study in the Jordanian banking sector. International Journal of Business and Management, 11(3), 95- 104,.

Apostolos, N., Giovanis, A., Binioris, S., \& Polychronopoulos, G. (2012). An extension of TAM model with IDT and security/privacy risk in the adoption of online banking services in Greece". Journal of Business, 7(1), 24-53,.Journal of Business and Management, 11(3), 95- 104.

Association of Banks in Jordan .(2018). http://www.abj.org.jo/ar-jo/directoryofbankingservices.aspx.

Bohmstedt, G. W. (1970). Reliability and validity assessment in attitude measurement (pp. 80-99). pp. 80-99. RandMcNally, IL, Chicago.

Calisir, F., \& Gumussoy, C. A. (2008). Online banking versus other banking channels: Young consumers' View". International Journal of Information Management, 28(3), 215 - 221,

Cao, M., Zhang, Q., \& Seydel, J. (2005). B2C e-commerce web site quality: an empirical examination. Industrial Management + Data Systems, 105(5), 645-661.

Casaló, L. V., Flavián, C., \& Guinalíu, M. (2008). The role of satisfaction and website usability in developing customer loyalty and positive word-of-mouth in the e-banking services. International Journal of Bank Marketing, 26(6), 399-417.

Davis, F., Bagozzi, R., \& Warshaw, P. (1992). Extrinsic and intrinsic motivation to use computers in the workplace". Journal of Applied Social Psychology, 22(14), 1111-1132,

Davis, F. D. (1989). Perceived usefulness, perceived ease of use, and user acceptance of information technology. MIS Quarterly: Management Information Systems, 13(3), 319.

Deraz, H., \& Iddris, F. (2019). Customers' satisfaction in internet banking: a review (2008-2017). 17. Utrecht.

Eriksson, K., Kerem, K., \& Nilsson, D. (2008). The adoption of commercial innovations in the former Central and Eastern European markets: The case of internet banking in Estonia. International Journal of Bank Marketing, 26(3), 154-169.

Featherman, M. S., Miyazaki, A. D., \& Sprott, D. E. (2010). Reducing online privacy risk to facilitate e-service adoption: the influence of perceived ease of use and corporate credibility. Journal of Services Marketing, 24(3), 219-229.

Haire, J. F., Bush, R. P., \& Ortinau, D. J. (2000). Marketing Research: A Practical Approach for the New Millennium. Sydney: Irwin McGraw-Hill.

He, F. \& Mykytyn, P. (2008). Decision factors for the adoption of e-finance and other e-commerce systems", available at https://pdfs.semanticscholar.org/a8b6/cc2522635b35638578f6c6bef87e34be6d13.pdf (accessed 17 June 2020).

Jahangir, N., \& Begum, N. (2007). Effect of perceived usefulness, ease of use, security and privacy of customer attitude and adaptation in the context of e-Banking". Journal of Management Research, 7(3), 147-157.

Jaruwachirathanakul, B., \& Fink, D. (2005). Internet banking adoption strategies for a developing country: the case of Thailand. Internet Research, 15(3), 295-311.

Karjaluoto, H., Mattila, M., \& Pento, T. (2002). Factors underlying attitude formation towards online banking in Finland. International Journal of Bank Marketing, 20(6), 261-272.

Kartiwi, M., \& Rfieda, A. (2018). Assessment of internet banking services continued use: Role of Socio-cognitive and relational view. TELKOMNIKA (Telecommunication Computing Electronics and Control), 16(6), 2817.

Katiyar, R., \& Badola, S. (2018). Modelling the barriers to online banking in the Indian scenario: an ISM approach". Journal of Modelling in Management, 13(3), 550-569,

Kesharwani, A., \& Singh Bisht, S. (2012). The impact of trust and perceived risk on internet banking adoption in India: An extension of technology acceptance model. International Journal of Bank Marketing, 30(4), 303-322.

Khan, I., Rahman, Z., \& Fatma, M. (2016). The role of customer brand engagement and brand experience in online banking. International Journal of Bank Marketing, 34(7), 1025-1041.

Kleinbaum, D. G., Kupper, L. L., Nizam, A., \& Muller, K. E. (1988). Applied Regression Analysis and Other Multivariate Medhods. Boston: PWS.

Kolodinsky, J. M., Hogarth, J. M., \& Hilgert, M. A. (2004). The adoption of electronic banking technologies by US consumers. International Journal of Bank Marketing, 22(4), 238-259.

Krisnato, U. (2017). Empirical study on the relationships of internet banking quality, customer value, and customer satisfaction”. Expert Journal of Marketing, 5(1), 17-27. 
Lassar, W. M., Manolis, C., \& Lassar, S. S. (2005). The relationship between consumer innovativeness, personal characteristics, and online banking adoption. International Journal of Bank Marketing, 23(2), 176-199.

Liang, C.-C., \& Pei-Ching, W. (2015). Internet-banking customer analysis based on perceptions of service quality in Taiwan. Total Quality Management \& Business Excellence, 26(5-6), 550-568.

Marakarkandy, B., Yajnik, N., \& Dasgupta, C. (2017). Enabling internet banking adoption: An empirical examination with an augmented technology acceptance model (TAM). Journal of Enterprise Information Management, 30(2), $263-294$.

Mojares, E. K. (2014). Customer satisfaction and loyalty among internet banking users of Philippine National Bank in Batangas City". Asia Pacific Journal of Multidisciplinary Research, 2(2), 41-48.

Nunnally, J.C. (1978). Psychometric Theory, McGraw-Hill, New York.

Oly Ndubisi, N., \& Sinti, Q. (2006). Consumer attitudes, system's characteristics and internet banking adoption in Malaysia. Management Research News, 29(1/2), 16-27.

Ong, K. S., Nguyen, B., \& Syed Alwi, S. F. (2017). Consumer-based virtual brand personality (CBVBP), customer satisfaction and brand loyalty in the online banking industry. International Journal of Bank Marketing, 35(3), 370-390.

Oweis, K. A., \& Alghaswyneh, O. F. (2019). The antecedents of electronic banking adoption in Saudi Arabia: Using Diffusion of Innovation Theory. Marketing and Management of Innovations, (4), 160-171.

Pan, Y., Luo, L., Liu, D., Gaom, L., Xu, X., Shen, W., \& Gao, J. (2014). How to Recommend by Online Lifestyle Tagging (OLT). International Journal of Information Technology \& Decision Making, 13(6), 1183-1209.

Pikkarainen, T., Pikkarainen, K., Karjaluoto, H., \& Pahnila, S. (2004). Consumer acceptance of online banking: an extension of the technology acceptance model. Internet Research, 14(3), 224-235.

Poon, W. (2007). Users' adoption of e-banking services: the Malaysian perspective. Journal of Business \& Industrial Marketing, 23(1), 59-69.

Rawashdeh, A. (2015). Factors affecting adoption of internet banking in Jordan: Chartered accountant's perspective. International Journal of Bank Marketing, 33(4), 510-529.

Raza, S. A., Jawaid, S. T., \& Hassan, A. (2015). Internet banking and customer satisfaction in Pakistan. Qualitative Research in Financial Markets, 7(1), 24-36.

Siam, A. Z. (2006). Role of electronic banking services on the profits of Jordanian banks". American Journal of Applied Sciences, 3(9), 1999 -.

Sikdar, P., \& Makkad, M. (2015). Online banking adoption: A factor validation and satisfaction causation study in the context of Indian banking customers. International Journal of Bank Marketing, 33(6), 760-785.

Sundarraj, R. P., \& Wu, J. (2005). Using information-systems constructs to study online- and telephone-banking technologies. Electronic Commerce Research and Applications, 4(4), 427-443.

Unyathanakorn, K., \& Rompho, N. (2014). Factors Affecting Customer Satisfaction in Online Banking Service”. Journal of Marketing Development \& Competitiveness, 8(2), 50-62.

Vivi, V., \& Novita, N. (2017). A study of the factors that influence the level of consumer satisfaction towards the use of internet banking. Jurnal Terapan Manajemen Dan Bisnis, 3(2), 87.

Wang, Y., Wang, Y., Lin, H., \& Tang, T. (2003). Determinants of user acceptance of Internet banking: an empirical study. International Journal of Service Industry Management, 14(5), 501-519.

Zabadi, A. M. (2016). Adoption of information systems (IS): The factors that influencing IS usage and its effect on employee in Jordan Telecom sector (JTS): A conceptual integrated model". International Journal of Business and Management, $5539(3), 25-36$,

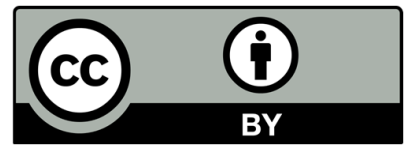

(C) 2021 by the authors; licensee Growing Science, Canada. This is an open access article distributed under the terms and conditions of the Creative Commons Attribution (CC-BY) license (http://creativecommons.org/licenses/by/4.0/). 